\title{
WATER QUALITY IN POKHARA: A STUDY WITH MICROBIOLOGICAL ASPECTS
}

\author{
Kishor Kumar Shrestha \\ Department of Civil and Geomatics Engineering \\ Pashchimanchal Campus, Pokhara \\ E-mail: kishor103@wrc.edu.np
}

\begin{abstract}
Obviously, water management is challenging issue in developing world. Dwellers of Pokhara use water from government supply along with deep borings and other sources as well. Nowadays, people are also showing tendency towards more use of processed water. In spite of its importance, quality analysis of water has been less emphasized by concerned sectors in our cities including Pokhara. The study aimed for qualitative analysis of water in the city with focus on microbiological aspects. For this purpose, results of laboratory examination of water samples from major sources of government supply, deep borings, hospitals, academic institutions as well as key water bodies situated in Pokhara were analyzed. Since water borne diseases are considered quite common in the area, presence of coliform bacteria was considered for the study to assess the question on availability of safe water. The result showed that all the samples during wet seasons of major water sources of water in Pokhara were contaminated by coliform bacteria. Likewise, in all 20 locations of Seti River, the coliform bacteria were recorded. Similar results with biological contamination in all samples were observed after laboratory examination of more than 60 locations of all three lakes: Phewa Lake, Begnas Lake and Rupa Lake in Pokhara. The presence of such bacteria in most of the water samples of main sources during wet seasons revealed the possibilities of spreading water related diseases. Again, microbiological contamination observed from significant number of bottled water samples as well as boring sources clearly alarmed the preoccupied belief in such supply of water. On the other hand, fluctuating water quality of academic institutions and hospitals questioned on the priority of the management and seriousness against possible spreading of water borne diseases. For obtaining the safe water, various treatment options have been recommended from World Health Organization (WHO) with chlorination in top priority due to affordability and simplicity. Urgent execution of such option could be important with due consideration of negative aspects from the possible byproducts. However, proper implementation of filtration technique and planning of further advanced technology could be valuable for fulfilling the need of metropolitan dwellers to get wholesome water for their daily consumption.
\end{abstract}

\section{Keywords}

Water quality, coliform bacteria, WHO, chlorination, sand filtration 
Nepal Engineers' Association, Gandaki 1. Introduction

Pokhara is the capital city of Gandaki Province in Nepal. The city was established as municipality in 1960 A.D. (2016 B.S.) meeting the immediate criteria of 5,000 population/ inhabitants for announcement of municipality (Pokhara Metropolitan City, 2020).

Table 1: Population of Pokhara (Nepal) in Different Years

\begin{tabular}{|c|c|c|c|}
\hline $\begin{array}{c}\text { S. } \\
\text { No. }\end{array}$ & $\begin{array}{c}\text { Year } \\
\text { (A.D.) }\end{array}$ & Population & Data Source \\
\hline 1. & 1952 & 3,755 & PSMC (1999) and \\
\hline 2. & 1961 & 5,413 & Adhikari (2000) \\
\hline 3. & 1971 & 20,611 & \\
\hline 4. & 1981 & 46,642 & \\
\hline 5. & 1991 & 95,268 & \\
\hline 6. & 1998 & 157,000 & \\
\hline 7. & 2008 & $2,26,000$ & (https: / / www. \\
\hline 8. & 2018 & $3,84,000$ & macrotrends.net/ \\
\hline 9. & 2020 & $4,21,000$ & $\begin{array}{l}\text { cities/23352/ } \\
\text { p o k h a r a / } \\
\text { population) }\end{array}$ \\
\hline
\end{tabular}

Similarly, population expansion rate in Pokhara is also following sharp trend with at least twice of national population growth rate while considering data since 1961 A.D. with some exception (Adhikari, 2000).

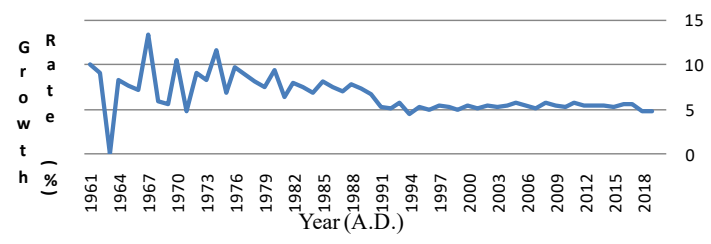

Figure 1: Population Growth Rate (\%) of Pokhara in Different Years

(Source: https://www.macrotrends.net/cities) On the other hand, there was excessively increasing tendency of built up area in Pokhara with continuous and significant reduction of cultivated land for the purpose of residential areas.

Table 2: Variation in Land Use Pattern of Pokhara

\begin{tabular}{lllll}
\hline $\begin{array}{l}\text { Y e a r } \\
\text { (A.D.) }\end{array}$ & $\begin{array}{l}\text { Built Up } \\
\text { Area (\%) }\end{array}$ & $\begin{array}{l}\text { Cultivated } \\
\text { Land (\%) }\end{array}$ & $\begin{array}{l}\text { Water } \\
\text { Body } \\
(\%)\end{array}$ & $\begin{array}{l}\text { Forest } \\
\text { Cover } \\
(\%)\end{array}$ \\
\hline 1977 & 6.33 & 60.73 & 13.97 & 1.52 \\
1990 & 20.08 & 52.76 & 12.38 & 1.36 \\
1999 & 33.66 & 38.70 & 12.84 & 1.57 \\
2010 & 51.42 & 20.27 & 12.69 & 2.21 \\
\hline
\end{tabular}

(Source: Rimal, 2013)

Such extremely increasing built up area has been leading towards demand of additional infrastructure facilities to cater the need of inhabitants in Pokhara and can be expected or even accelerating the same with its progress for international air connectivity. The situation is challenging the infrastructure needs of Pokhara including aspects of transportation, residence, health and education facilities including water and waste water management. Out of these, management of water with quality as per standard could be a major aspect of study.

Globally, maintaining water quality is quite big issue. As per World Health Organization (WHO), only $71 \%$ people are considered to have access to safely managed drinking water system. On the other hand, more than 2 billion people are considered to use drinking water sources contaminated with human waste (including feces). Moreover, about 297,000 children/infants are losing their life every year from diarrhea caused by improper water quality with lack of hygiene and sanitation (https:// www.who.int/news-room/fact-sheets/detail/ drinking-water). Again, 1.8 Million people died from water related diseases in 2015 according to 
The Global Burden of Disease Study (Biswas and Tortajada, 2019). Again, a study of government schools in India revealed that $39.8 \%$ of water samples were observed unfit for drinking with coliform bacteria (Sidhu et. al.; 2016).

It is precious to state that, the United Nations General Assembly (UNGA) recognized access to safe and clean drinking water and sanitation as a human right in 2010 in spite of enough challenges for attaining quality water in least developed countries (https://en.unesco.org/ waterquality-iiwq/wq-challenge). Though United Nations' Sustainable Development Goal (SDG) No. 6 has set target to provide access to safe drinking water for $100 \%$ of the population in each country, socio-economic constraints, lack of monitoring and reporting water quality data and reduction of water pollution are major barriers (Metcalf et. al; 2017) to achieve the same within mentioned time frame.

Table 3: Water Quality of Various Rivers in Nepal

\begin{tabular}{lllll}
\hline Location/River & $\mathbf{p H}$ & $\begin{array}{l}\text { Total } \\
\text { Solids }(\mathbf{m g} / \mathbf{l})\end{array}$ & $\begin{array}{l}\text { Dissolved } \\
\text { Oxygen (mg/l) }\end{array}$ & $\begin{array}{l}\text { Dissolved } \\
\text { Biochemical } \\
\text { Demand (BOD) (mg/l) }\end{array}$ \\
\hline Mechi & 8.3 & 30 & 8.9 & 1.8 \\
Kankai & 7.7 & 60 & 8.7 & 2.0 \\
Arun & 6.2 & 222 & 9.1 & 2.1 \\
Seti (at Ramghat Pokhara) & 8.2 & 208 & 9.3 & 2.0 \\
Bheri (at Chatgaon) & 7.8 & 208 & 9.3 & 1.1 \\
Karnali (at Chisapani) & 7.8 & 264 & 10.5 & 1.5 \\
Mahakali (at Panchesor) & 8.8 & 110 & 5 & 2.0 \\
WHO Guideline Value & $6.5-8.5$ & 100 & $>5$ & 3 \\
\hline
\end{tabular}

(Source: CBS, 2019)

Though Environmental Statistics of Nepal (CBS, 2019) showed the physical, chemical and biological aspects of water quality in major rivers of Nepal were observed within the standard range of World Health Organization (WHO), water from only $29 \%$ of deep wells in context of Kathmandu Valley was observed drinkable while considering the presence of Escherichia coli (Sakamoto, 2012). Similarly, analysis of water samples collected from Dug wells (37 samples), Shallow Tube Wells (38 samples), Stone Spouts/Dhunge Dhara (16 samples), Deep Tube Wells (5 samples) and Municipal Sources (19 samples) in Kathmandu revealed that samples from all the sources had E. Coli as well as Total Coliform bacteria showing contamination in major sources of water supply to the consumers in the capital. In this case, $86 \%$ samples from Dug Wells were detected with microbiological pollution (Warner et.al.; 2008) followed by Municipal Sources with 73\%. Moreover, the two third of samples with presence of total coliform bacteria while analyzing water quality of the metropolitan also insisted to be serious about water quality issue in Kathmandu (Tamrakar et.al.; 2017).

On the other hand, all water samples from Mardi River (Major water source of Pokhara) were observed with coliform bacteria (Shah, 2012). Similar result was achieved with presence of the same bacteria while analyzing water quality of Seti River (https://opendatanepal. com). Moreover, only about 55\% coverage in 
Nepal Engineers' Association, Gandaki

Pokhara was observed to meet the water quality standard with national average value of $43 \%$ in overall water systems of Nepal (NWSC, WSMB and KUKL, 2016).

Such situations clearly indicated that microbiological aspects of water quality is quite essential part to be analyzed since people are getting troubled water related diseases with lack of safe water. Following excessive growing trend of urbanization in Pokhara with more than $50 \%$ land area covering by the built up area (Rimal, 2013) along with lack of standard water treatment process, it could be valuable to analyze about quality of supplied water. Of course, focus on microbiological pollution is precious for prevention of water related diseases mostly occurring in cities of Least Developing Countries (LDCs) including Pokhara. Till now, quality of water from individual source of was analyzed by many researchers but there was lack of overall approach to discuss about the water quality in Pokhara including water sources as well as water bodies. Such study gap impelled to assess overall water quality in context of Pokhara considering microbiological aspects.

\section{Objectives of Study}

The key objective of this study was to analyze water quality of various sources and locations of Pokhara considering microbiological aspects. The study aimed to cover major water sources including surface water and ground water, lakes and river including important institutions along with processed water in Pokhara, Nepal as well. Moreover, recommendation of appropriate measures for water quality improvement was also intended by this study.

\section{Study Area}

The study area; Pokhara is a well-known metro city in Nepal for natural beauty with area of $464.24 \mathrm{Sq}$. Km. The city was formally announced as metropolitan city on 10th March 2017 A.D.
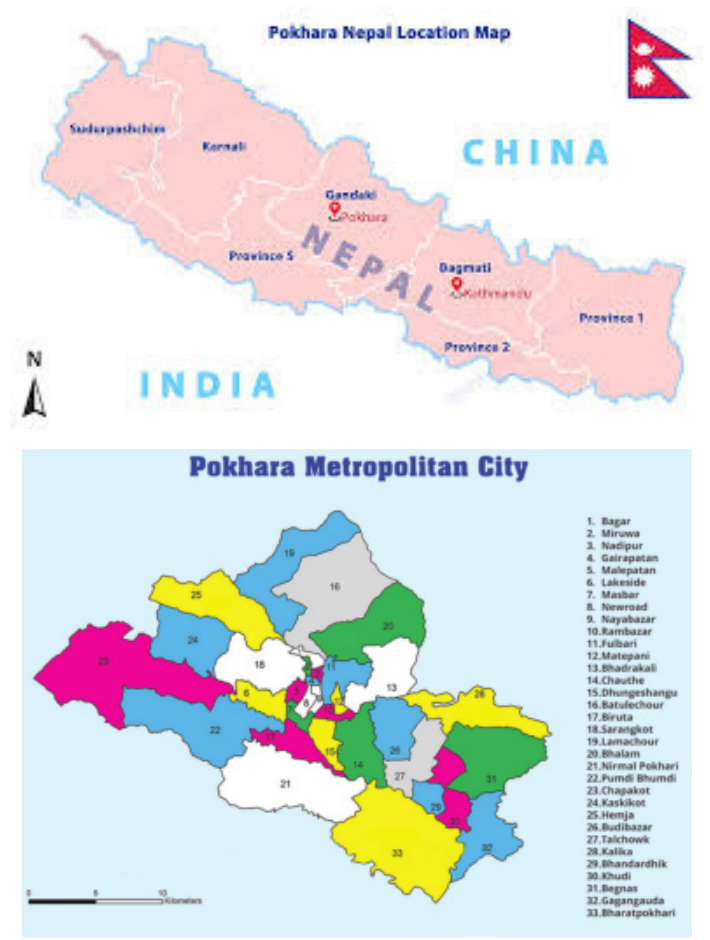

Figure 2: Pokhara Metropolitan City with Its Coverage Area

(Source: Pokhara Metropolitan City, 2020)

containing 33 divisions (wards) which enclosed former Pokhara Sub-metropolitan City, Lekhnath Municipality and various villages namely; Mauja, Chapakot, Bhadaure Tamagi, Kaski Kot Majhthana, Kalika and Puranchaur (http:// pokharamun.gov.np/content). In this article, major sources of water in Pokhara along with key water bodies were covered for this analysis as following.

Sources of Water: Mardi River, Bhoti Khola, Majhkuna Spring, Baldhara Spring, Ghattekhola 
Spring, Kalimudha Spring.

Water Bodies: Seti River, Phewa Lake, Rupa Lake, Begnas Lake.

Deep Borings: Phulbari, Lamachaur, Bagar, Rastrabank Chowk, Shreekrishna Chowk, Rambazaar

Hospitals: 14 Hospitals in Pokhara.

Academic Institutions: 4 Government Campuses (Higher Educational Institutions) in Pokhara.

\section{Study Methodology}

Available resources including research articles on different aspects of Pokhara as well as publication from Pokhara Metropolitan City Office were consulted in this study. Similarly, various statistical data concerned with infrastructures and population trend in Pokhara were also considered. Likewise, References related to the water quality in the study area along with concerned data from environmental statistics of Nepal were followed during this review.

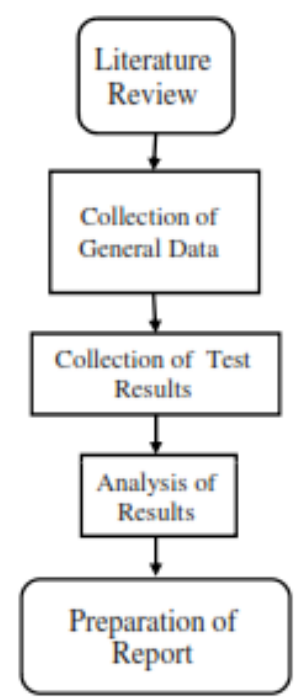

Figure 3: Flow Diagram of Study Methodology
For data analysis with focus on microbiological aspects, water quality results obtained from project works as well as outputs of academic research works focusing key water sources/ water bodies of Pokhara area were considered for this article.
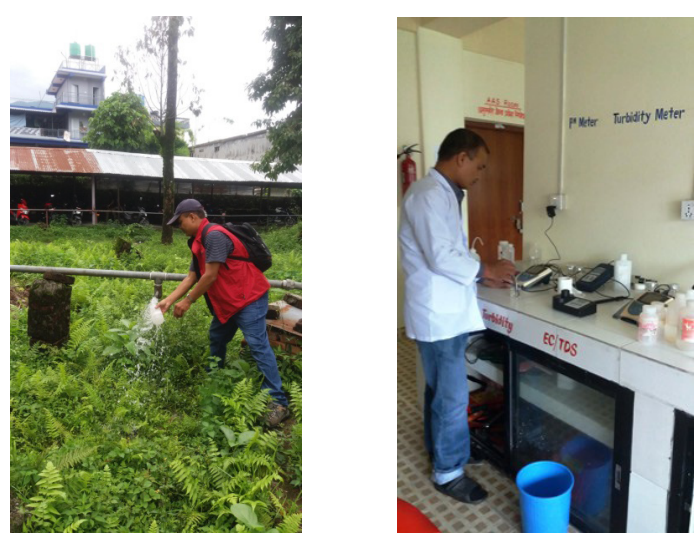

Figure 4: Water Sample Collection and Laboratory Examination

These results of quality examination of water samples from hospitals, academic institutions, sources, processed water bottles, deep borings as well as lakes (Phewa Lake, Begnas Lake, Rupa Lake) and river (Seti River) were mainly considered for analysis in this study. Such examination of water quality of collected water samples were conducted in water laboratories following standard procedures including tube test kits and membrane filtration for microbiological quality assessment for academic purpose by corresponding individual or group after collection of water samples accordingly.

\section{Results and Discussion}

\subsection{Water Quality of Sources}

Study of water quality at major sources of Pokhara revealed the microbiological water pollution. 
Nepal Engineers' Association, Gandaki

Table 4: Status of Coliform Bacteria at Water Sources of Pokhara

\begin{tabular}{llll}
\hline Description & \multicolumn{2}{l}{$\begin{array}{l}\text { Status of } \\
\text { Bacteria }\end{array}$} & \\
& $\begin{array}{l}\text { Dry } \\
\text { Season }\end{array}$ & $\begin{array}{l}\text { Wet } \\
\text { Season }\end{array}$ & \\
& - & Present & Mardi Intake 1 \\
\hline Source 1 & - & Present & Mardi Intake 2 \\
Source 2 & - & Present & Bhotikhola Intake 1 \\
Source 3 & - & Present & Bhotikhola Intake 2 \\
Source 4 & - & Present & Majhkuna Spring \\
Source 5 & - & Present & Ghattekhola Spring \\
Source 6 & - & Present & Kalimudha Spring \\
Source 7 & - & Present & Baldhara Spring \\
Source 8 & - & &
\end{tabular}

(Source: Bhatta et. al. 2014)

during wet season in most of the cases. On the contrary, it clearly indicated absences of coliform bacteria in all water samples of the water sources (Bhatta et. al.; 2014). Similar result was obtained by Shah (2012) while determining water quality index of Mardi River (major source of water supply in Pokhara) with all water samples at all five locations having presence of coliform bacteria. Presence of fecal coliform could be due to disposal of household waste including night soil being carried by storm water.

\subsection{Water Quality of Hospitals}

Since the healthcare facilities are places to improve health condition, it could be worth to assess whether people are susceptible to water related diseases by consuming water in such institutions or not. Following water quality examination in these locations, water samples from 5 out of total 14 hospitals in Pokhara were having coliform bacteria during dry season. On the other hand, $85.7 \%$ water samples were observed with the same bacteria from the results of water quality examination of wet municipal supply of water with microbiological contamination and lack of institutional treatment works could be major reason for such poor water quality in both seasons.

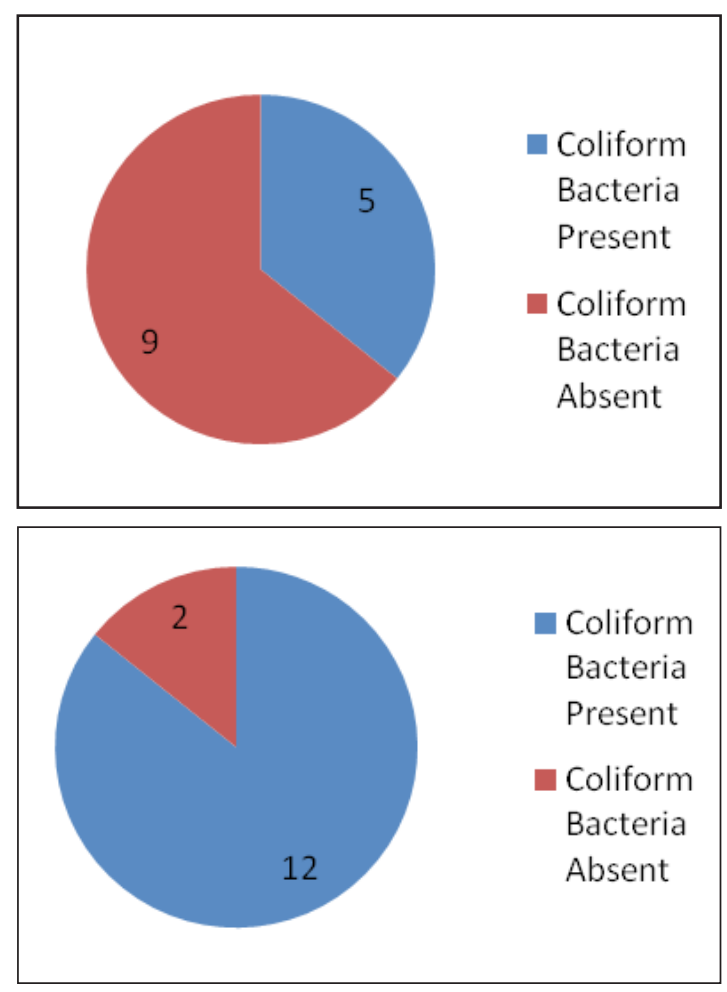

Figure 3: Number of Hospitals in Pokhara with Status of Coliform Bacteria in Water Samples of Dry Season and Wet Season (Thakali et. al; 2015)

The scenario revealed the poor water quality condition of hospitals in Pokhara with need of further improvement before consumption or even critical use including medical/surgical purposes.

\subsection{Water Quality of Bottled Water}

A microbiological study of bottled/processed drinking water in Pokhara indicated the presence of total coliform in 38\% monsoon water samples out of 21 brands though there was absence of the same in pre-monsoon water 
samples (Maskey et. al.; 2020). Significant presence of coliform bacteria in water samples at monsoon season indicated the lack of proper quality management of water processing plants questioning the consistency of the treatment processes. This scenario also expressed the poor quality of bottled water during rainy season against the general public consideration of proper water quality and belief as well.

Table 5: Total Coliform Risk of Bottled Drinking Water

\begin{tabular}{|c|c|c|}
\hline $\begin{array}{l}\text { Range of Total } \\
\text { Coliform } \\
(\mathrm{CFU} / 100 \mathrm{ml})\end{array}$ & $\begin{array}{l}\text { Number of } \\
\text { Pre-monsoon } \\
\text { Samples }\end{array}$ & $\begin{array}{l}\text { Number of } \\
\text { Monsoon } \\
\text { Samples }\end{array}$ \\
\hline 0 & - & 13 \\
\hline $1-10$ & - & 4 \\
\hline 11-100 & - & 1 \\
\hline 101- >1000 & - & 3 \\
\hline
\end{tabular}

(Source: Maskey et. al.; 2020)

\subsection{Water Quality at Deep Borings}

While analyzing water quality of deep borings at government and other sectors, the water samples were observed with absence of coliform bacteria during dry season compared to their presence in some cases of wet season. Infiltration of surface water polluted with waste water could be the cause of positive cases during wet season.

Again, results showing the coliform bacteria during wet season mentioned the need of improving water quality of deep borings before drinking or other consumptions.
Table 6: Status of Total Coliform in Boring Water Samples

\begin{tabular}{|c|c|c|c|}
\hline \multirow{4}{*}{ Description } & \multicolumn{3}{|c|}{ Status of } \\
\hline & \multicolumn{2}{|c|}{ Coliform Bacteria } & \multirow{3}{*}{${ }^{\mathrm{a}}$ Remarks } \\
\hline & Dry & Wet & \\
\hline & Season & Season & \\
\hline \multicolumn{2}{|c|}{ Deep Boring 1- } & - & Fulbari \\
\hline \multicolumn{2}{|c|}{ Deep Boring 2- } & - & Shreekrishna Chowk \\
\hline \multicolumn{2}{|c|}{ Deep Boring 3- } & Present & Rastra Bank Chowk \\
\hline \multicolumn{2}{|c|}{ Deep Boring 4- } & - & Lamachaur Boring \\
\hline \multicolumn{2}{|c|}{ Deep Boring 5- } & - & Bagar Boring \\
\hline \multicolumn{2}{|c|}{ Deep Boring 6- } & - & Ramghat Boring \\
\hline \multicolumn{2}{|c|}{ Deep Boring 7- } & Present & Phulbari Boring \\
\hline \multicolumn{2}{|c|}{ Deep Boring 8- } & - & Private Boring \\
\hline
\end{tabular}

(Source: Bhatta et. al. 2014)

\subsection{Water Quality at Higher Education Institutions}

Obviously, it could be an important aspect to know about the quality of water being consumed in the academic institutions where concerns of water are being discussed/analyzed. A study on water quality analysis at four higher education institutions/campuses at Pokhara revealed that the water samples were free from Escherichia coli at pre-monsoon samples against presence with significant numbers at post-monsoon samples (Shrestha, 2020).

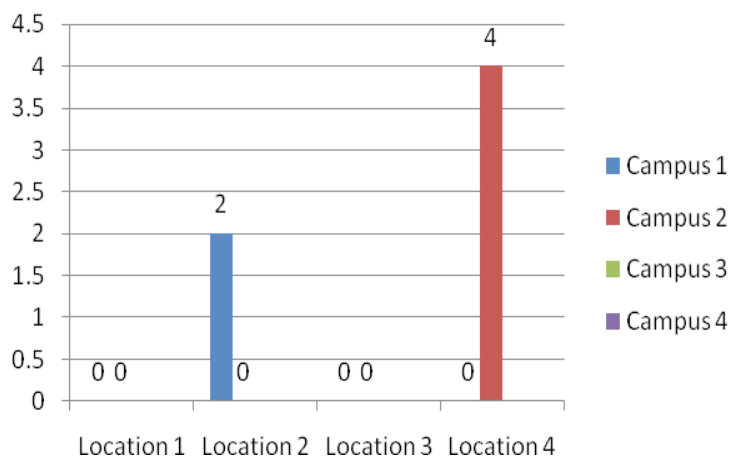

Figure 4: Presence of Escherichia coli in Post Monsoon Water Samples from Higher Education Institutions (Source: Shrestha, 2020) 
This scenario of microbiological contamination in ground water at these academic institutions could be due to contamination of such water sources demanding greater depth to extract water without influence of pollution during rainy season.

\subsection{Water Quality at Lakes and River}

Corresponding studies on water quality analysis of three lakes and Seti River in Pokhara also pointed out poor conditions with presence of Escherichia coli (E.coli) in water samples collected at all sampling locations of Seti River (20 sampling locations), Phewa Lake (20 sampling locations), Begnas Lake (23 sampling locations) and Rupa Lake (21 sampling locations) as per Paudel (2019) and Sadadev (2019).

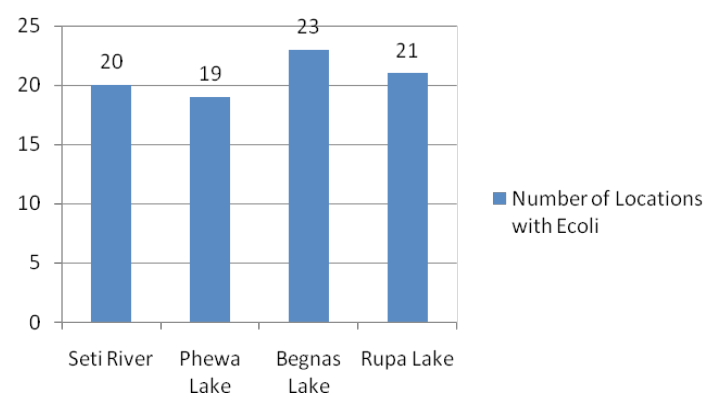

Figure 5: Presence of Escherichia coli in Water Samples of Lakes and River

(Source: Paudel, 2019 and Sadadev, 2019).
Of course, observation of all water samples with presence of E.coli in Seti River and three lakes of Pokhara could be a vital issue. It would be significant to mention the examples of directly visible cases of disposing toilet/ septic tank effluents from households/ commercial structures in Seti River/Lake. Moreover, improper management or even lack of management of fecal waste in surroundings of the sources and direct discharge of produced waste water from many areas could be major reasons beyond the scenario with great challenge in government policy of reviving the water bodies in pristine condition. Also, lack of water quality in such major tourist destinations of Pokhara might influence the hesitation in recreational activities with direct impact on socio-economic and cultural aspects.

\subsection{Summary of Water Quality Results}

While analyzing data concerned with microbiological water quality results in various sources/sectors of water supply in Pokhara, most of the samples showed the condition of pollution while comparing with the standard value to be nil as per National Drinking Quality Standard (MoPPW, 2005) as well as guidelines from $\mathrm{WHO}$ (WHO, 2017). 
Table 7: Summary of Microbiological Water Quality Results

\begin{tabular}{lccc}
\hline Description & $\begin{array}{c}\text { Sampling } \\
\text { Locations }\end{array}$ & $\begin{array}{c}\text { Positive Result of } \\
\text { Microbiological Analysis }\end{array}$ & $\begin{array}{c}\text { Status of Micro- } \\
\text { biological Pollution }\end{array}$ \\
\hline Sources(Dry Season) & 8 & Nil & \\
Sources (Dry Season) & 8 & 8 & Polluted \\
Hospitals (Dry Season) & 14 & 9 & \\
Hospitals (Wet Season) & 14 & 21 & \\
Bottled Water & 21 & Nil & \\
Boring Water (Dry Season) & 8 & 2 & \\
Boring Water (Wet Season) & 8 & Nil & \\
Higher Education Institutions (Pre-monsoon) & 12 & 6 & \\
Higher Education Institutions & (Post- & 12 & 20 \\
monsoon) & & 19 & \\
Seti River & 20 & 23 & \\
Phewa Lake & 20 & 21 & \\
Begnas Lake & 23 & 21 & \\
Rupa Lake & 23 & & \\
\hline
\end{tabular}

\subsection{Discussions for Quality Improvement}

The scenario of microbiological pollution essentially demanded immediate need of efficient water purification method to be applied before consumption of water from the mentioned sources/locations challenging the current measures (with chlorination applied in government supply only).

In this consequence, CAWST (2009) has stated chlorination to be efficient for removal of bacteria and effective for killing virus, protozoa and helminthes as well.

As per Drinking Water Quality Guidelines of World Health Organization (2017), appropriate Methods for water purification are chlorination as well as filtration. Though membrane technologies as well as granular activated carbon treatments are the advanced ones, cost effectiveness as well as technical complexity is key issues associated.
Table 8: Appropriate Water Purification Process Recommended by WHO

\begin{tabular}{ll}
\hline Ranking & Treatment Process \\
\hline 1 & Simple Chlorination \\
2 & $\begin{array}{l}\text { Plain Filtration (Rapid Sand, Slow } \\
\text { Sand) } \\
3\end{array}$ \\
4 & Pre-chlorination + Filtration, Aeration \\
& Granular Activated Carbon (GAC) \\
5 & Treatment, Ion Exchange \\
6 & Ozonation \\
& Advance Oxidation Processes, \\
\hline
\end{tabular}

(Source: WHO, 2017)

While using appropriate treatment for removal of microorganisms, one crucial aspect is to consider the effect of disinfection by product (DBP) mainly after chlorination. Since formation of Trihalomethane (THM) can form if chlorine combines with Humic Acid/ 
Nepal Engineers' Association, Gandaki

Fulvic Acid from organic content in water which may lead for carcinogenic conditions (https://www.cdc.gov). Such scenario shall be addressed by considering short term (including chlorination) and long-term Methods (sand filtration, membrane technology) of killing microorganisms in water.

Table 9: Removal efficiencies of various Point of Use (PoU) Treatment System Options

\begin{tabular}{|c|c|c|c|}
\hline $\begin{array}{c}\text { Water } \\
\text { treatment } \\
\text { method }\end{array}$ & $\begin{array}{c}\text { Removal of } \\
\text { Turbidity }\end{array}$ & $\begin{array}{c}\text { Removal } \\
\text { efficiency } \\
\text { of Fecal } \\
\text { Coliform }\end{array}$ & Reference \\
\hline $\begin{array}{l}\text { B i o-s a nd } \\
\text { filter }\end{array}$ & $98 \%$ & $\begin{array}{l}99.1-99.9 \\
\%\end{array}$ & $\begin{array}{l}\text { S a g a r a , } \\
1999\end{array}$ \\
\hline $\begin{array}{l}\text { C e r a m i c } \\
\text { filter }\end{array}$ & $94 \%$ & $92 \%$ & $\begin{array}{l}\text { Shrestha et } \\
\text { al., } 2007\end{array}$ \\
\hline $\begin{array}{l}\text { Chlorine } \\
\text { s o } 1 \text { utio n } \\
(0.5 \%)\end{array}$ & NA & $>99 \%$ & $\begin{array}{l}\text { https:// } \\
\text { www.who. } \\
\text { int/water_ } \\
\text { sanitation_ } \\
\text { health }\end{array}$ \\
\hline SODIS & NA & $90-95 \%$ & $\begin{array}{l}\text { Shrestha et } \\
\text { al., } 2007\end{array}$ \\
\hline $\begin{array}{l}\text { Boiling (5 } \\
\text { minutes) }\end{array}$ & NA & $99.999 \%$ & $\begin{array}{l}\text { https:// } \\
\text { www.who. } \\
\text { int/water_ } \\
\text { sanitation_ } \\
\text { health }\end{array}$ \\
\hline
\end{tabular}

On the other hand, application of point of use (PoU) water treatment at household/ institutional level could also be a valuable option. Since most of the water samples were observed with the coliform bacteria, Bio-sand filter, use of chlorine solution (with managing the effect of DBP) or even boiling (in small level) could be precious to cope the issue of microbiological contamination since all these Methods are stated to have efficiency more than $99 \%$ to remove fecal coliform.

\section{Conclusions}

The water quality studies undoubtedly mentioned theapparentstatus of microbiological pollution in major water sources including samples from underground water sources, Seti River and three lakes in Pokhara. With the background of commonly spreading usual water borne diseases, immediate actions shall be executed to prevent/control the possible situation. Chlorination, being the easiest approach, can be applied as a immediate solution with due consideration of possible negative consequences of disinfection by products. However, long term strategy shall be valuable to plan and execute including efficient sand filters or even membrane technology. Ongoing construction of filtration works shall be expected to be significant to manage the crucial condition following timely completion with efficient results for purification to provide clean and safe water in Pokhara. Of course, regular analysis of water quality through academic studies/research could be precious for monitoring and addressing such critical issue directly related to the public health in the metropolitan city towards fulfilling the people's right for obtaining safe water.

\section{Limitations}

This review article was based upon analysis of water quality from various sectors in Pokhara withlaboratory results of collected watersamples during various studies including academic project works/dissertations. The corresponding results at particular period of time/season were consulted following the experimental analysis with available procedures. Detailed analysis applying standard procedures with sufficient and frequent samples could be important for more precise results. 


\section{Acknowledgment}

I would like to appreciate graduate students; Bishnu Poudel, Biwas Babu Sadadev, Shailendra Kumar Shah, undergraduate students; Anil K. Bhatta, Binod Adhikari, Dinesh Lamichhane, Kamal Kandel, ManzilShrestha and Maya Gaire, Astha Thakali, Babita Sharma, Binita Poudel and Kabita Poudel for their contribution including laboratory examinationfor water quality during their dissertations/project works. Also, my sincere gratitude to Pashchimanchal Campus, Institute of Engineering, Pokhara and Institute of Forestry, Pokhara Campus for opportunity to supervise dissertations/project works.

\section{References}

Adhikari, Jagannath (2000). Urbanization, Government Policies and Growing Social and Environmental Problems in Pokhara, Nepal. Studies in Nepali History and Society 5(1): 43-88 (retrieved from http:// www.martinchautari.org.np/files/SINHASArticles/SINHAS-Vol.10-No.2_JagannathAdhikari.pdf).

Bhatta, A., Adhikari, B., Lamichhane, D. Kandel, K., Shrestha, M. and Gaire, M. (2014). Status of Water Supply System in Pokhara Sub-metropolitan City, final year project report submitted to the Department of Civil Engineering, Pashchimanchal Campus, Institute of Engineering, Pokhara, Nepal, 2014.

Biswas, A. and Tortajada, C.(2019). Water quality Management: a Globally Neglected Issue, International Journal of Water Resources Development, Volume 35, No. 6 (DOI: 10.1080/07900627.2019.1670506), 2019.

CBS (2019). Environmental Statistics of Nepal 2019, Central Bureau of Statistics,
Kathmandu, Nepal, 2019.

https://en.unesco.org/waterquality-iiwq/wqchallenge cited on $21^{\text {st }}$ August, 2020.

http://pokharamun.gov.np/content cited on $23^{\text {rd }}$ July, 2020.

https://www.cdc.gov/safewater/chlorinationbyproducts.html cited on $24^{\text {th }}$ July, 2020.

https://www.macrotrends.net/cities/23352/ pokhara/population cited on $22^{\text {th }}$ July, 2020. https:/ / opendatanepal.com/dataset/ analysis-of-water-samples-from-fourpoints-of-seti-river-at-pokhara/ cited on $20^{\text {th }}$ August, 2020.

https://www.who.int/news-room/fact-sheets/ detail/drinking-water cited on $20^{\text {th }}$ August, 2020.

https://www.who.int/water_sanitation_ health/dwq/Boiling_water cited on $21^{\text {st }}$ August, 2020.

https://www.who.int/water_sanitation_ health/ cited on $21^{\text {th }}$ August, 2020

Maskey, M., Annavarapu, L.S., Prasai, T. and Bhatta, D.R. (2020). Physical, Chemical and Microbiological Analysis of Bottled Water in Pokhara, Nepal, an article in Journal of Chitawan Medical College, 2020, Nepal.

Metcalf, C. , Gupply, L. and Qadir, M. (2017). Global Barriers to Water Quality: a Critical Review, Report Series, Issue 02, United Nations University Institute for Water, Environment and Health, Hamilton, Canada, 2017.

MoPPW (2005). National Drinking Water Quality Standards- 2005, Implementation Directives for National Drinking Water Quality Standards, Ministry of Physical Planning and Works, Kathmandu Nepal, 2005.

NWSC, WSMB and KUKL (2016). Water Service Providers Capacity Assessment 
Nepal Engineers' Association, Gandaki and Benchmarking, Data Year 201415, Sector Efficiency Improvement Unit (SEIU), Ministry of Water Supply and Sanitation, Government of Nepal, 2016.

Paudel, B. (2019). Assessment of Spatial Variation of Water Quality in Seti River, Pokhara, a project report submitted to M.Sc. Infrastructure Engineering and Management Program, Department of Civil and Geomatics Engineering, Pashchimanchal Campus, Pokhara, Nepal, 2019.

Pokhara Metropolitan City, 2020. Brief Introduction, a Brochure of Pokhara Metropolitan City (retrieved from http:// pokharamun.gov.np/sites/pokharamun.gov. np/files/Broucher_0.pdf, cited on $22^{\text {nd }}$ July, 2020).

Rimal, B.(2013). Urbanization and the Decline of Agricultural Land in Pokhara Sub-metropolitan City, Nepal, Article published on Journal of Agricultural Science, Vol. 5, No. 1: 2013, ISSN 1916 $-9752$.

Sadadev, B. (2019). Comparative Study of Water Quality Index of Phewa, Rupa and Begnas Lakes, a project report submitted to M.Sc. Infrastructure Engineering and Management Program, Department of Civil and Geomatics Engineering, Pashchimanchal Campus, Pokhara, Nepal, 2019.

Sagara, J. (2000). Study of Filtration for Point of Use Drinking Water Treatment in Nepal, M.E. Thesis in Civil and Environmental Engineering, Department of Civil and Environmental Engineering, Massachusetts Institute of Technology, USA, 2000.
Sakamoto, S., Nishida, K. Kazama, F., Imaizumi, Y., Hiraga, Y., Nakamura, T. and Chapagain, S. (2012). Microbial Pollution in Groundwater and Surface Water of the Kathmandu Valley, cited from Kathmandu Valley Groundwater Outlook, Shrestha, S., Pradhananga, D., Pandey, V.P., Eds.; Asian Institute of Technology (AIT): Klong Luang, Pathumthani, Thailand, 2012.

Shah (2012). Water Quality Assessment of Mardi River by Water Quality Index, M.Sc. Thesis submitted to Institute of Forestry, Pokhara, Nepal, 2012.

Shrestha, K. (2020). Analysis of Drinking Water Quality of Constituent Campuses of Tribhuvan University in Pokhara, Nepal, a mini research report submitted at Research Management Unit, Pashchimanchal Campus, Pokhara, Nepal, 2020.

Shrestha, R.R., Jackson, D., Maharjan, M., Raut, R., Sing, P. and Maskey, A. (2007). A Summary Paper on Efficiency of Household Water Treatment Technologies in Nepal on Candle filters, Bio-sand Filters, Terracotta Filters and SODIS, 2007.

Sidhu, S., Malhotra, S., Devi, P. and Gupta, A., (2016). Bacteriological Analysis of the Drinking Water from Different Schools in Northern India: A Concern in Developing Countries, an article in Internal Journal of Medical Research and Review, Volume 4, Issue 4, DOI: https://doi.org/10.17511/ ijmrr.2016.i04.26, 2016.

Tamrakar, P., Shakya, S. and Baniya, C. B. (2020). Physico-chemical and Bacteriological Composition in a Metropolitan Drinking Water Distribution System in Kathmandu, an article in Journal of Institute of Science and Technology, 
Volume 22, Issue 1 (ISSN: 2469-9062) 2017.

Thakali, A., Sharma, B., Poudel, B and

Poudel K. (2015). Analysis of Water

Supply Management in Hospitals in

Terms of Quality and Quantity: Case

Study in Pokhara Sub-metropolitan City,

a final year project report submitted to the Department of Civil Engineering, Pashchimanchal Campus, Institute of Engineering, Pokhara, Nepal, 2015.

Warner, N.R., Harpp, K.S., Levy, J. and Farruggia, F.T. (2008). Drinking Water Quality in Nepal's Kathmandu Valley: A Survey and Assessment of Selected Controlling Site Characteristics, an article in Hydrology Journal, Volume 16, Issue 2 (DOI: 10.1007/s10040-007-0238-1), 2008.

WHO, (2017). Guidelines for Drinking-water Quality, Fourth Edition, Published by World Health Organization, 2017. 